\title{
Miscellany
}

\section{BUPA Foundation Communication Award}

The BUPA Foundation is supporting the Communication Award again in 1998, in association with the Academy of Medical Royal Colleges and the Patients Association. There will be two prizes of $\$ 10000$ each, one for work completed by individuals or a group of individuals, and one for work undertaken by a college, institution, hospital or professional body. Further information: Lady Nourse, 12 Old Square, Lincoln's Inn, London WC2A 3TX (Tel: 0171404 0809; Fax: 01718318096 )

\section{Initial Health Personnel launches locum service}

Initial Health Personnel has recently launched a new locum doctor service that is available to all hospitals and medical practices throughout the UK. Their on-call services enable clients and staff to obtain assistance and advice between the hours of $6 \mathrm{a} . \mathrm{m}$. and $10.30 \mathrm{p} . \mathrm{m}$. For further information contact David Fallows at Initial Health Personnel on 01716081899 or e-mail: pr@rentokil-initial.com.

\section{Accident Line - a helping hand for all students}

Formed by the Law Society, Accident Line is a freephone referral service for all those who need legal advice about an injury suffered through an accident. The service provides the caller with the number of a specialist personal injury solicitor, who will offer a free $\mathbf{3 0}$ minute consultation to assess the grounds for proceeding, including eligibility for Legal Aid. Freephone 0500192939.

\section{Patient Advocacy Working Party}

The Public Policy Committee of the College has set up a small working party to look at the role of patient advocacy in mental health and learning disability services. The working party intends to produce a College policy document in the important area based on examples of good practice. The working party would like to hear from Members of the College who have had experiences, good and bad, with patient advocacy services. Please could anyone wishing to reply write to Deborah Hart, at the External Affairs Department.

\section{New publications}

The Manic Depression Fellowship (MDF) has recently published a booklet to provide help and coping strategies for those who care for people with manic depression. Approved by the Department of Health and the Royal College of Psychiatrists, copies of Balancing Act are available for $\$ 2.50$ (inc. $p \&$ p) from The Manic Depression Fellowship, 8-10 High Street, Kingston-upon-Thames, Surrey KTl IEY (Tel: 0181974 6550; Fax: 0181794 6600).

\begin{tabular}{|c|}
\hline EUROPEAN PSYCHIATRY: A FORCE FOR THE FUTURE \\
THE BEST AND WORST OF ACADEMIC PSYCHIATRY \\
Professors of Psychiatry (PoP) Club and \\
Proceedings of the: \\
Association of Professors of Psychiatry's First European Meeting (July 1996) \\
Edited by: Hamid Ghodse and David Goldberg \\
Copies available from: Department of Psychological Medicine \& Centre for Addiction Studies \\
St George's Hospital Medical School, Hunter Wing, Cranmer Terrace \\
LONDON SW17 0RE Tel: +44 (0)181 725 5718 \\
For further details and/or an order form please contact the above number quoting: \\
"The Best and The Worst of Academic Psychiatry", ISBN 18977783 X, at a cost of $£ 5.00$ per copy \\
(plus $£ 1.50$ postage \& packaging). Cheques payable to: St George's Hospital Medical School
\end{tabular}

